\title{
Antonio da Noli and the Discovery of Cape Verde: A Legacy in Dispute: Italy, Portugal and Cape Verde
}

\author{
Luca Bussotti ${ }^{1,2}$ \\ ${ }^{1}$ Federal University of Pernambuco, Program of Post-Graduated Studies in Sociology and Institute of African Studies, Recife, \\ Brazil \\ ${ }^{2}$ International Studies Centre, ISCTE/IUL, Lisbon, Portugal \\ Email: labronicus@gmail.com
}

How to cite this paper: Bussotti, L. (2020). Antonio da Noli and the Discovery of Cape Verde: A Legacy in Dispute: Italy, Portugal and Cape Verde. Advances in Historical Studies, 9, 153-173. https://doi.org/10.4236/ahs.2020.94014

Received: September 16, 2020

Accepted: November 16, 2020

Published: November 19, 2020

Copyright ( 2020 by author(s) and Scientific Research Publishing Inc. This work is licensed under the Creative Commons Attribution International License (CC BY 4.0).

http://creativecommons.org/licenses/by/4.0/

(c) (i) Open Access

\begin{abstract}
This study aims to shed some light on an ambiguous, historical figure of Modern European and African history, Antonio da Noli, who lived during the 15th century. Various sources presented Antonio da Noli as the "discoverer" of Cape Verde, although other versions of history indicate the Venetian Alvise da Ca' da Mosto and the Portuguese Diogo Gomes as the possible discoverers of this Atlantic archipelago. Additional sources defend that Cape Verde was first discovered by African and Arab populations before the arrival of the Portuguese navigators. This study, through a historical analysis of primary sources of the same navigators here considered, as well as secondary sources of Italian, Portuguese and Cape-Verdian authors, aims at presenting how some of the historical dark points of the life and maritime adventures of Antonio da Noli have been used by three fundamental historiographical traditions, each with different political objectives: the Italian, the Portuguese and the Cape Verdeans. The conclusion is that Antonio da Noli and the discovery of Cape Verde left an ambiguous legacy which until today is in dispute between nationalism, colonialism and post-colonialism.
\end{abstract}

\section{Keywords}

Discovery, Ideology, Historiography, Nationalism, Colonialism and Post-Colonialism

\section{Introduction}

An ambiguous legacy characterizes the historical figure of Antonio da Noli, an Italian navigator who, under the orders of the Portuguese crown, supposedly 
discovered the Cape Verde Islands in the 15th century. Historical sources are quite uncertain regarding his life and adventures as an Atlantic explorer, since unlike other navigators such as the Venetian Alvise da Ca' da Mosto (1966) and the Portuguese Diogo Gomes, he did not leave any written documentation.

This research does not intend to clarify the historical facts that still continue to be debated among researchers. Rather, its aim is to show how various ambiguous biographical elements of Antonio da Noli's life induced scholars to neglect him as a historical figure for a long time, who then re-emerged at approximately the beginning of the 19th century: first, in Italy, during the Italian Risorgimento and the period of Fascism as a worthy representative of his homeland. Then in Portugal as a historical figure connected with Diogo Gomes, and, in Alvise da Ca' da Mosto's memories, as a discoverer of the Cape Verde colony. In the case of Portugal, starting from the $500^{\text {th }}$ anniversary of the discovery of this archipelago in 1960, the Portuguese figure Diogo Gomes, tended to prevail in national historiography, diminishing Antonio da Noli's role. Finally, in Cape Verde, a former Portuguese colony that obtained its independence on July 5, 1975, the discovery of this archipelago was presented ambiguously first, and especially during the colonial period, showing historiographical and political positions very similar to those of its motherhood, thus revealing a radical bifurcation after its independence between those who intend to forget the colonial past of Cape Verde as a whole by breaking down the statues from that period, and those who yet organize celebrations to honor that discovery.

The use of historical figures at different times is common. In many cases, this is a process with evident political and ideological bias. In general, the attempt is to show the link between a certain historical figure and a new national tradition (Hobsbawm \& Ranger, 1983). In this case, this research tries to show how the figure of Antonio da Noli was interpreted and used in different countries such as Italy, Portugal and Cape Verde, according to the different ideologies these countries emphasized, with meaningful differences also inside each country.

For the Italian case, two great traditions were called into question. The first was developed in the $18^{\text {th }}$ century and embedded in its romantic ideology of a country that was looking for an actual political independence, which emphasized Antonio da Noli's spirit of freedom. Antonio da Noli became a disputed figure among Ligurian and Venetian scholars, and, within the first group, further so between Genoese and Noli scholars. Here, an important role was played by a tradition rooted in municipalism, which directly reflected on the approach to the debate (Putnam, Leonardi, \& Nanetti, 1993; Meriggi \& Schiera, 1993). With the advent of Fascism, this municipal tradition was incorporated into a broader ideology of an Italian nationalism, with clear colonial roots, deriving from the new African adventures of Mussolini and his regime.

In Portugal, the dispute that occurred during the $19^{\text {th }}$ century did not see the prevalence of a single position. Nevertheless, some authors began to spread the idea that Cape Verde was discovered by Diogo Gomes, which diminished the respective roles of the other two Italian navigators, Alvise da Ca' da Mosto and 
Antonio da Noli in relation to the country's discovery. As a matter of fact, only in 1960 , on the occasion of the $500^{\text {th }}$ anniversary of Cape Verde's discovery, Portuguese scholars demonstrated a systematic attempt to exalt the figure of Diogo Gomes, promoting his image in the same insular colony (Barros, 2017). This historiographical and political position resulted from a long process of strengthening the Portuguese Salazarian nationalism, which started in the 1930's with the Colonial Act (1930) and with the Constitution of 1933, and which found in the celebrations of 1960 a moment of exaltation in a new form of relationship with its colonial countries (Ferreira Cascão, 1992). At least this was the intention of Salazar.

Finally, in Cape Verde, the diversification of the various positions between colonial and post-colonial approaches was yet even more evident than in Italy and Portugal, as described below.

\section{A Historical Overview}

Antonio da Noli lived in the $15^{\text {th }}$ century. He was probably born in 1419 , and his main professional experiences are related to the sea, its economy and politics. $\mathrm{He}$ came from Liguria, a Northern maritime region of Italy, where Genoa was the most important city and port-one of the four independent maritime republics that dominated the Mediterranean Sea. Genoa had signed deals with various neighboring minor ports. Among them, was that of Noli, a small town where the navigator Antonio was probably born, even though there are doubts about his birth place.

Noli was known as the fifth Italian maritime republic and as the town of the "72 towers". Its first participation in an important international event was in 1096-1099, on the occasion of the first crusade promoted by Pope Urban II. Under this circumstance, Noli sent a trireme ship with about one hundred sailors, together with other ships. In one of them, Tancredi would find hospitality and for this reason, he exempted Genoa, Savona and Noli from the payment of taxes in the conquered towns and ports, as a thank you gesture for their commitment.

In 1192, Noli acquired the status of "free Municipality", probably thanks to a sale of assets of Del Carretto's family, which had dominated the town for almost two centuries. A political turning point occurred in 1202, when the Municipality of Noli decided to forge a strong alliance with its powerful neighbor, Genoa, in opposition to the ghibelline Savona and the Marquisate of the Final. From this moment, Noli's future would be directly tied to Genoa's which left some administrative autonomy to its ally to be in charge of its protection.

Noli took advantage of this political option, becoming an important hub for trade and manufacturing, especially ship-building. Its main foreign order came from France, when in 1268-1269, Saint Louis, then king of France, requested some galleys to be made in Noli.

The strategic position of Noli for the Guelph option could be motivated by the fact that "the popes, in general of Italian origins, favored the civil liberties of the municipalities (...), meanwhile the foreign emperor stifled their breath". For this 
reason, Noli's people were proud to spread the Pope's cause, together with the cause of Genoa (Descalzo, 1943).

This attitude gave the chance to Noli to acquire the status of an autonomous Episcopal seat and it detached from Savona in 1239 (and until 1820). Despite the fact that during the 15th century, Noli suffered a period of slow decline, the town was able to maintain its independence until 1797 when it fell under the rule of the French, who were occupying a great part of Northern Italy.

The maritime power of Genoa reached its apogee between the $14^{\text {th }}$ and $15^{\text {th }}$ century. Nevertheless, from the West of Italy something important changed the nature of international relations among the various European States, as well as the same general weltanshaaung ("vision of the world"): and this great transformation came from the sea.

Beginning in the $13^{\text {th }}$ century, Portugal decided to acquire a key position in the European geopolitics, entering in competition with the main maritime powers of that period, such as Genoa and Venice, on one side, and England and Flanders on the other side. In order to do this, Portugal boosted its economic relations with the main European ports, building an efficient fleet for the defense of its boasts and of its maritime space. The year 1317 is considered as a turning point: the Portuguese King, D. Dinis, invited the Genoese Emanuele Pessagna (Manuel Pessanha) to cover the charge of the "Royal Galleys Admiral". At least 20 Genoese sailors with a large experience in the nautical art had to accompany him to Portugal, with the aim to teach to the Portuguese sailors this activity that Dinis considered crucial for the development of his country (Radulet, 1983: pp. 26-27).

A new social actor was emerging: an autochthonous bourgeoisie, "but with strong lies to foreign" (Radulet, 1983: p. 29). This emerging new middle class showed great interest in the promotion of explorations and discoveries. At the same time, the old aristocracy, whose ideal and religious version was the struggle against the Moors, aimed at carving out a geopolitical space at the international scale. This scenario could have integrated different needs of key parts of the Lusitanian society. Also, thanks to a new political stability, whereby since 1383 the d'Avis dynasty reigned in Portugal, and the same for Castile, in 1411, which recognized Portugal's independence under a peace treaty that guaranteed a definitive consecration at the international scale (Tenenti, 1980). In addition, Portugal developed new techniques of navigation that had been introduced by Chinese and Arabs, such as the compass, building of agile caravels, nautical charts and astrolabe. Together, this allowed Portugal to begin its famous Atlantic adventures.

The first explorations were initiated by Prince Henry the Navigator, Duke of Viseu and the fifth son of King John I. Motivated with religious spirit, he participated to the conquest of Ceuta, an Arab outpost in Morocco that fell under the control of Portugal in 1415. This represented a key logistical point of reference and a reason for a young Christian nation to be proud while taking its first steps in the geopolitical international chessboard during that period. 
After gaining this victory, Henry settled down in the Sagres Peninsula, in the Southern region of Algarve between Lagos and Cape Saint Vincent, "an extreme corner of the world, where you really get the feeling that the land ends and the sea begins" (Ferro, 1980: p. 80). Prince Henry (Zuarara, w.d.; Zuarara, 1915; Lopes, 1960; Caraci, 1961) obtained substantial benefits and funding from the Portuguese crown to begin the Atlantic explorations, whose main aim was the conquest of the "Indies" and knowledge of the area of Africa (currently Ethiopia) managed by a priest, John. This priest had to serve, according to the intentions of Henry, as an important ally to fight the Arab resistance inside Africa, enabling expansion and the Lusitanian trades.

In this historical context, it is necessary to frame the story of Antonio da Noli along with other Italian navigators-as the Venetian Alvise da Ca' da Mosto (Bussotti, 2008) - who decided to put their work and their seafaring experience at the service of the Portuguese crown. Portugal was the only kingdom, in the central period of the $15^{\text {th }}$ century that guaranteed great opportunities for work, combining economic benefits with the spirit of adventure and fame that every navigator at the time looked for.

As it will be shown below, the growing Portuguese resourcefulness was worrying for the other European nations at the time, especially Castile. This State, between 1475 and 1479, under the rule of Queen Isabel, carried out what has been defined as "the first of the colonial wars among European powers", against Portugal and its growing Atlantic dominion (Russell, 1971: p. 5). One of the main objectives of this conflict was the control of Cape Verde, and in particular, Santiago Island, which was occupied in 1476 by the Captain Carlos de Valera, who encountered there, Antonio da Noli, serving as a governor under the Portuguese King.

This war ended with a diplomatic victory for Portugal. Prince Henry had already obtained, through various Papal bulls, the "exclusivity" on Atlantic navigations and trades: Pope Martin V had emitted, immediately after the conquest of Ceuta, the bull Sane charissimus (1418). Therefore, when a new dispute for the control of Canary Islands arose, Pope Eugene IV tried to appeal it, through the bull Dudum cum ad nos. In 1452, Pope Nicholas V, with the bull Dum diversas, expanded the benefits in favor of the Portuguese, "authorizing them not only to make war on the Moors, but also to invade and conquer their lands and the lands their occupied, although if belonging to other princes or kings" (Radulet, 1983: p. 236). Nevertheless, the bull which established and defined the division of the new territories among the European powers, especially Portugal and Castile, was the Romanus Pontifex, emanated on January $8^{\text {th }}, 1455$ by the same Nicholas V, which was later confirmed by his successor, Calixtus III, through the bull Inter Cetera. In addition, Henry was authorized to occupy the Cape of Bojador.

Strengthened by such Papal positions, Portugal arrived at the Treaty of Alcáçovas (September $4^{\text {th }}$, 1479) with Castile under the firm intention to have the confirmation of its monopoly on African lands, Azores, Madera and Cape 
Verde, while Castile would have confirmation of its control of the Canary Islands. This treaty was later confirmed by the Papal bull Aeterni regis, emitted by Sixtus IV in 1481: it induced Castile to direct their naval adventures no more towards Africa or the Indian Ocean, but more towards the West.

\section{Antonio da Noli's Life: Its Dark Points and Other Suspended Historical Issues}

The historical context described above presents the background of Antonio da Noli's life. In this chapter, the main dark points of a historiographical debate that triggered harsh disputes among various groups in different historical periods are presented. The starting point of these disputes is marked by some biographic highlights of Antonio da Noli's life, which crosses relevant historic events involving at least three countries (Italy, Portugal and Cape Verde) and various interpretative and ideological tendencies.

Point One: the identity of Antonio da Noli. For many years, Antonio da Noli was often confused by many scholars, including the Italian Enciclopedia Europea Garzanti (Enciclopedia Europea, 1976: p. 514) with another Italian navigator, Antoniotto Usodimare. However, thanks to documented evidence, today it is clear that Antonio da Noli was not Antoniotto Usodimare. This was one of the most important conclusions of a series of studies that culminated in an international congress convened in 2010 in Noli, and thus resulting in a related collective book (Peluffo, 2013).

Point Two: the place of birth of Antonio da Noli. It is historically impossible to establish where he was born. As Peluffo stated, this curiosity cannot be satisfied since the surname of his family before moving to Noli is still yet unknown (Peluffo, 2013). What is possible to state here is that (as it will be shown below) the importance of Antonio da Noli's birth place does not only have interest from a mere historical perspective, but even more so that in Italy the geopolitical issues that were based on a local pride represented for a long time the reasons for a harsh dispute between Genoa and Noli.

Point Three: the discovery of Cape Verde. This point represents the most serious element for a political debate, which began in the 15th century, involving two other Italian figures, as Alvise da Ca' da Mosto and Antoniotto Usodimare, to the detriment of Antonio da Noli, besides the Portuguese Diogo Gomes. It is worthy saying that today, thanks to recent studies, the historical debate established that Antonio da Noli was indeed the first to discover and manag at least a part of the Cape Verde Archipelago (Santiago Island), having received a concession of the King of Portugal (Peluffo, 2013). Nevertheless, a long historiographical debate characterized this fact, as shown below.

Point Four: this issue concerns the question regarding who firstly discovered Cape Verde. Was it anyone coming from Europe, at the service of the Portuguese crown? Or was it anyone belonging to an African population which had already inhabited this Atlantic archipelago before the arrival of the Portuguese navigators? In this case as well, it is impossible to give a definitive answer. 
Someone defended that "it is possible to find evidence on the presence of human groups in Cape Verde before the arrival of the Portuguese, according to the main writings of the end of the $18^{\text {th }}$ century"-alluding to a black population coming from Senegal or to Arabs (Andrade, 1992). It still seems certain that these human groups were insignificant, in quantitative terms, and that they did not populate the islands of Cape Verde before the arrival of the Portuguese. As Andrade noted, that population "does not seem to have constituted a population important enough and solidly established to offer some resistances to the Portuguese colonial settlement" (Andrade, 1992: pp. 6-7). Nonetheless, this question gained importance especially in Cape Verde after its independence from Portugal, with some scholars and local activists defending a new "African theory" of the discovery of this archipelago.

Point Five: as a matter of fact, historically proven, Antonio da Noli was the first duly appointed governor of Cape Verde by the Portuguese king. he established his residency in Ribeira Grande, and thus began to populate this new colony. This privilege was confirmed in 1466, when he obtained the authorization to practice the slave trade in Guinea, with the franchise of export rights to Madera and Azores Islands. If there are serious doubts on who discovered for the first time the islands of Cape Verde, there is no doubt that Antonio da Noli was who, due to his skill and ability, obtained at least their partial management, gradually and periodically increasing his privileges and becoming a reference and focal point for the Atlantic expansion of Portugal. Here, it is worth remembering that Antonio da Noli continued to be the governor also when the Castile Kingdom conquered Cape Verde, as well as when this archipelago came back into the hands of the Portuguese crown. This circumstance too gave rise to many speculations, which will be illustrated below.

\section{The Rediscovery of Antonio da Noli between Nationalism, Colonialism and Post-Colonial Perspectives: Italy, Portugal and Cape Verde}

While the lack of written documentation represents a serious gap for historical work, this circumstance actually helped to trigger a long debate on the figure and "myth" of Antonio da Noli, as well as on the discovery and administration of Cape Verde in the broader context.

With this in mind, the five aforementioned "dark" points were then developed, in taking a first time look at the domestic debate in Italy, Portugal and Cape Verde, therefore drawing general conclusions.

\subsection{Antonio da Noli and the Italian Debate}

For many centuries, the figure of Antonio da Noli was forgotten in the Italian historical debate, in favor of other Italian navigators, such as the Venetian Alvise da ca' da Mosto. This is due to the fact that the Venetian navigator was the author of interesting books, and he reached enormous fame during his lifetime. The attempt to recover the history and image of Antonio da Noli came from his 
fellow citizens, at least at first. For instance, Bernardo Gandoglia, a historian of Noli origin, wrote the following: "Antonio da Noli can be defined as the last luminous meteor that illuminates the sunset of his homeland. His soul, buried for four centuries of foreign and civil oppression, shines today (late justice!) of an unusual splendor" (Gandoglia, 1885).

In this case, the forgotten biography of Antonio da Noli was interconnected with the history of Italy, characterized by many centuries of foreign oppression, where every kind of research on individuals who contributed to the strengthening of Italian nationalism was banned. Nonetheless, especially from the 19th century, the nationalistic spirit of independence encountered a rapid growth in Italy, therefore the name of Antonio da Noli was rediscovered and his fame finally embedded in the political environment of Italian Risorgimento and in winning political independence in 1861 .

Although Antonio da Noli was included in Italian history, in the $19^{\text {th }}$ century and in the first two decades of the following century his figure was an object of heavy debate embedded into a local and municipal tradition, traditionally very strong in Italy. In a general sense, Antonio da Noli was considered as a paradigmatic character of the Italian genius, devoted to the Pope and, consequently, authentically Christian and engaged in the discovery of a new world and in the civilization of native people.

Due to his public image, Antonio da Noli became a disputed figure among, at first, Venetian and Ligurian scholars, and especially the Genoese. As a first aspect of the debate, this dispute was based on the unknown birthplace of the navigator Antonio, a question left mainly to a dispute among Ligurian scholars.

Today there are three main hypotheses about the birthplace of Antonio da Noli. Besides Noli and Genoa, a third possibility, which is currently the most credible, is that Antonio da Noli was born in Serra Riccò, near Genoa (Noli, 2013a), where exists a small area called Noli, or in Voltri. In Serra Riccò in 2009, a legal descendant of this navigator, Marcello Ferrada de Noli, founded the Antonio de Noli Academic Society, a centre of research that produced interesting and new documentation on the life of Antonio da Noli ${ }^{1}$.

During the $19^{\text {th }}$ century, various historical speculations were advanced in order to support various political and local orientations. The dispute concentrated its focus on the Genoa-Noli confrontation.

The greatest defender of Noli thesis was a prestigious source, Descalzo. In his opinion, Antonio da Noli was born in Noli, as the word "Da" ("from" in Italian) would indicate. He concluded as follows, arguing against his Genovese colleagues, as Father Spatorno: “... it is necessary to address a few words to Father G. B. Spatorno and to some Genoese writers who want him Genoese at any cost, trying to steal this glory to Noli, as if their city suffered of lack of illustrious men! (...) The Genoese shouldn't claim our Antonio da Noli as a Genoese" (Descalzo, 1943). Finally, Descalzo pointed out that the main doubts on the birthplace of ${ }^{1}$ For more information on the activity of The Antonio de Noli Academic Society see https://ferrandoli.wordpress.com/the-antonio-de-noli-academic-society/. 
Antonio da Noli came from Italian authors, meanwhile foreign researchers never questioned on this point. According to Descalzo, this dispute would have, as its main objective, to "snatch" such important figure to Noli, in favor of Genoa.

If this detail seems insignificant from a historical point of view, from the perspective of the building of a local tradition this is a very important issue. This local tradition intends to use Antonio da Noli as its main basis to strengthen a myth of a small town such as Noli as a historically free and autonomous land, passing from Risorgimento to Fascism, into the Italian political context.

In addition to Descalzo, other authors emphasized the importance of the birthplace of the navigator Antonio in Noli. For instance, the philosopher Anacleto Verrecchia stated the following: "And we have to remember another navigator, whose tombstone is near that of Giordano Bruno: Antonio da Noli" (Verrecchia, 2002: p. 49). This Noli position automatically disavowed the hypothesis which identified Antonio da Noli with Antoniotto Usodimare, another Genoese navigator at the service of the Portuguese crown, which sailed with Alvise da Ca' da Mosto to navigate the River Gambia (Salvadori, 1942).

The dispute about Antonio da Noli reached its peak moment in the debate on the discovery of Cape Verde. In this case, the above-mentioned debate on his birthplace stems from the Ligurian frontiers, entering into dispute especially with Venetian scholars interested in defending the navigator Alvise da Ca'a da Mosto as the discoverer of Cape Verde.

The Venetian Zurla reiterated that the discovery of Cape Verde had to be attributed to his fellow citizen, Alvise da Ca' da Mosto. In the Introduction of his book, Zurla presented his main objective regarding the two travel reports written by Alvise da Ca' da Mosto: “To others (...) instead of to him the discovery of the Islands of Cape Verde was attributed; (...). Finally, others (...) considered his travels and discovers lightly, reducing them almost to nothing". The authors who represent the target of the criticisms of Zurla are two Venetian scholars, who defended the discovery of Cape Verde by Antonio da Noli, as endangering the Venetian patriotism: the two are the Abbot Bettinelli (1786) and the authors of the Istoria Generale de' Viaggi (Prevost D'Exiles, 1784). About the latter, Zurla pointed out that "this injustice is amazing in these Authors", indicating contradictory elements between the first and the sixth of their volumes. Zurla reiterated-speaking of Alvise da $\mathrm{Ca}$ ' da Mosto-that "behind the fame of his first discovery, others followed him", mentioning explicitly Antoniotto Usodimare (Zurla, 1815).

On the Genoese side, an illustrious figure such as the Marquis Girolamo Serra attributed the discovery of Cape Verde to Antoniotto Usodimare (never identified as coming from Noli), quoting Portuguese sources of that period (Zurla, 1815). Father Spotorno, a Barnabite priest and famous scholar of Ligurian literature, defends the same interpretative line. The relevant point defended by Spotorno, quoting Barros, is a Ligurian interpretation of the discovery of Cape Verde, defining Alvise da Ca' da Mosto as "a ridiculous swanker" (Spotorno, 1824-1826). 
The aforementioned debate on the discovery of Cape Verde was characterized by strong municipal tones, which only the competition with Portugal, firstly, and secondly with the advent of Fascism and its process of "nationalization" were able to forge into an accelerated process of "Italianization". Local pride never disappeared, and it became a function of the patriotic spirit of the time, and Antonio da Noli therefore rose to national status.

At the beginning of the 19th century, when Italian patriotism did its general trials for the First World War, an Italian historian accused the Portuguese navigator Gomes and his book of memories to be mendacious and unreliable, with the only objective to bring out his gray figure to the detriment of the brilliant and successful Antonio da Noli. "Brightly attesting the glory of Antonio da Noli, these documents reject claims of hypercritics or novels of deceivers, as that of Diego Gomez, who accumulated every kind of falsity to make yourself believe a great unrecognized navigator" (Pescio, 1913: p. 94).

According to political orientations, during Fascism, the two first dark points of the biography of Antonio da Noli were removed definitively, and the potential conflict with Portuguese nationalism ceased. Antonio da Noli became a navigator coming from Noli, clearly distinguished from Antoniotto Usodimare and seen as a paladin of the Italian heroism. The culmination of this process of "rediscovery" of Antonio da Noli was marked by the initiative of the Podestà (the Fascist Mayor) of Noli, together with some deputies of this city, having as its aim to "canonize", to "fascistize" and to nationalize this navigator.

With a tone of pleasure, Descalzo described this municipal initiative. In addition, Descalzo reported the short message that Mussolini sent to Noli, on the day dedicated to the celebration of the navigator Antonio (August 23, 1925). Paolo Borselli: "All the Navy lives of its glorious marinating braveries stop. In the a glorification of Anton da Noli it is present stop. Mussolini”. Together with the new flag on the municipality of Noli, this ancient maritime republic is represented by Fascism as a "nest of daring navigators and an unsurpassed bulwark over the centuries against Saracen raids" (Descalzo, 1943). In his speech, Ferruccio Latini announced that "a scout ship of our glorious Navy" assumed the denomination of "Antonio da Noli". A very vehement speech was pronounced by the Podestà, Vittorio Garzonel, who underscored the patriotism of Antonio da Noli: "this intrepid sailor runs to give shine to the Motherland thanks to his great geographical explorations, arriving first, with courage and skill, on those uncharted seas, which will give glory to his successors: Christopher Columbus and Vasco da Gama" (Descalzo, 1943).

It is interesting to note the reasons why the process of Italian canonization of Antonio da Noli by the Fascist regime culminated in the attribution of the name of this navigator to a naval destroyer. Antonio da Noli was associated to a wide group of Italian navigators and explorers "of all time" with the aim to update the denominations of the navy of the kingdom (Ufficio del Capo di Stato Maggiore della Regia Marina, 1931). General Ceci, who was commissioned to investigate on the figure of Antonio da Noli, concluded that this Ligurian navigator had all 
the features to be part of this special category of people "who honored the Italian lineage” (Ufficio del Capo di Stato Maggiore della Regia Marina, 1931: p. 3).

Built in the Cantieri del Tirreno Riva Trigoso for the Italian navy, and reclassified in 1938 as a naval destroyer ship, the "Antonio da Noli" carried the seaplanes of Italo Balbo which realized the Italy-Brazil air crossing. After the armistice of September 8, 1943, this destroyer ship battled against Hitler's German navy, eventually sinking after clashes and hitting a mine.

Another important point of the Italian debate about the figure of Antonio da Noli lies in his activity as an administrator of Santiago Island. Here, two different interpretations in Italian historiography have to be presented: the first is expressed by the Fascist Descalzo, and the second by a contemporary historian, Giulia Lanciani.

A first comment on the role of Antonio da Noli as a governor of Cape Verde was given by Pescio, who lived in a pre-fascist period during the first year of the 19th century, which was imbued with nationalism. The navigator Antonio was considered as a perfect example of someone who spread the principles of a "good civilization", according to a perspective embedded in a colonial spirit. Pescio, speaking of Cape Verde, described Antonio da Noli as the one that this archipelago "had revealed to civilization (...), showing himself as a wise colonizer as well as a wonderful navigator" (Pescio, 1913).

Antonio da Noli is represented by other Ligurian authors of the 1920s-1930s as an excellent manager, who contributed to civilize an indigenous population, winning against the resistance of a hostile nature.

Nevertheless, it was the Fascist regime that captured the representation of Antonio da Noli as an exemplar governor, and someone who was able to convert and civilize "inferior" human beings. As a matter of fact, the Ligurian navigator established at Santiago "his own home, becoming the Governor, the educator and the father, dying there in 1496, with the saint name of Patriarchy, after having converted the indigenous people to the Christian religion and after having taught them much of the arts, the industries and agriculture". The author concluded "with devoted and fascistic gratitude": "I, at the name of this ancient maritime town, which had a conspicuous part in the history of the Crusades in the chronicles of the ancient trade of the East (...) respectfully ask for, as in the case of the other discoverers and great navigators, remembrance of Anton da Noli by the Italian people" (Descalzo, 1943).

The attempt of Fascism is clear: Antonio da Noli carried out those activities that Mussolini also implemented in his colonial campaign in Africa. Therefore, Antonio da Noli is represented as a fascist ante litteram, embodying perfectly the Roman spirit. In this context, also, the competition with Portuguese nationalism suffered a drastic decrease, due to the political affinity between the two regimes.

As Descalzo remembered, a fertile collaboration between Mussolini and Salazar originated a deal signed in 1939 at Salt Island, retracing the exploits of the navigator Antonio, who helped Prince Henry in his Atlantic discoveries. This new cooperation resulted in a "perfect aerodrome from where all our vehicles of 
the postal service in the ocean leap started, in the eve of Christmas 1939, returning the archipelago its primitive function of stopover and trampoline for a quickest connection between Europe, Africa and the Americas". Mussolini's brother, Bruno Mussolini, implemented this important initiative, and he "landed in Salt Island coming from Villa Cisneros". Thanks to this initiative by Mussolini, Descalzi concluded, a new importance was assumed by "the Islands of Antonio". It couldn't miss honorable mention of the small city of Noli: "The maritime Noli (...) has the right to be proud of its most eminent son" (Descalzo, 1943).

In many circumstances, the representation made by Fascism of Antonio da Noli went beyond the simple consideration of his role of manager of Santiago Island. In particular, two important facts have been interpreted according to the personal features of Antonio da Noli, which allowed him to overcome very complicated situations.

The first fact has to do with the impact of the Castilian-Luso war, which ended with the aforementioned Treaty of Alcáçovas. The islands of Cape Verde were involved in this conflict, promoted by Queen Isabel. Better stated, one of the main objectives of that first Euro-Atlantic conflict was just the control of Santiago, which was conquered on March 28, 1476, by the Castilian army. The Castilian captain, Carlos de Valera, captured Antonio da Noli, who was brought before the queen. Despite being a prisoner, he convinced the Castilian kings to confirm him as an island administrator.

The same situation occurred after the signing of the Treaty of Alcáçovas, when Cape Verde was returned to Portugal. In this case too, Antonio da Noli, initially supposed betrayer, was confirmed in his role of island manager.

In order to understand how Antonio da Noli could continue to maintain his role under such difficult circumstances, an interesting debate ensued involving critical approaches within the Italian debate.

Nevertheless, one of the first historians to underline this strange circumstance was the British Russell. He defined the adventure of Antonio da Noli as a "curious story", starting from his first meeting with the King of Castile. After a quick dialogue with "Fernando the Catholic" in Medina del Campo, he obtained his designation as Castilian governor of Santiago" (Russell, 1971: pp. 19-20).

On the other hand, Ligurian authoritative sources ignored this phase. For instance, Descalzo did not mention the "curious story" reported by Russell, pointing out the role of Cape Verde at the international scale, which Antonio da Noli contributed to build.

Nonetheless, Descalzo reported another meaningful fact in the book Giro del mondo del buon negriero, which reveals his ideology regarding the adventure of Antonio da Noli and his role in the Atlantic trade-reorganized by Emilio Radius for Bompiani, with a witness, Francesco Carletti, from Florence, who reached Cape Verde in 1594. Carletti's trip was organized by his father with hopes to "improve his conditions" (Carletti, 1941). The destination chosen was Cape Verde, "to buy Moors for the Western Indies" (Descalzo, 1943). No doubt, thus, that at the end of the 16th century the archipelago played a strategic role in 
the slave trade. Descalzo concluded as follows: "The Carletti pages are the best documentation (...) of the value Antonio da Noli's navigations and discoveries had for the subsequent explorations and the rapid flowering of the trade" (Descalzo, 1943).

Descalzo presented Antonio da Noli as a skilled trader, indicating him to be the one who promoted the historical function of Cape Verde as a logistics centre for the slave trade. The same Descalzo told of a rather unpleasant episode between Gomes and Antonio da Noli about the slave trade: "When Diego Gomez (...) tried to trade slaves in Zaza harbor, he was painfully affected by the rise in 'good' price: while before they should have bought twelve 'Niggers' in exchange of only one horse, now they offered him only seven; the arrival of other European caravans full of horses had caused a market alteration. A Ligurian, Antonio da Noli, had preceded him!" (Descalzo, 1943).

The representation of Descalzo regarding Antonio da Noli reveals how much the Fascist regime gave value to the management of Cape Verde. No illusion was made regarding the role of Antonio da Noli as a slave trader. Rather, this figure was exalted for his craftiness in relation to his Portuguese colleague. And this situation, according to Descalzo, put into evidence the superiority of the Italian genius from the first years of Modernity, in a celebration of nationalistic pride.

Beyond the slave trade, Antonio da Noli had probably a perfect knowledge also of other kinds of trade, primarily that of gold. This aspect of Antonio da Noli was pointed out only recently by an Italian historian, Lanciani. According to her, Antonio da Noli "occupies a privileged position knowing the Guinean commercial system as a whole, including the famous Gold Mine. In fact, he controls the critical point of the Portuguese Ultramar" (Lanciani, 2006).

Antonio da Noli became the best and maybe the only profound connoisseur of the trading system of that strategic area, thereby making him too important to get rid of him. This was validated by the Castilian Kings when they conquered Cape Verde, as well as for the Portuguese King, when Cape Verde returned in the hands of the Lusitanian Crown.

In this case, it too was necessary to wait for contemporary research directed to explain the attitude of Portugal towards Antonio da Noli in this difficult situation. And, in this case, the interpretation of Fascism regarding Antonio da Noli and his work as a governor of Santiago is deeply reviewed.

Regarding the facts that led to the Alcáçovas Treaty, Lanciani stated that "In exchange for his release, Antonio da Noli demonstrated to be a precious informant of the Portuguese's enemies" during his short Castilian prison (Lanciani, 2006: p. 53). This interpretation is not very far away from that of Russell, who had defended a thesis of an implicit pact of Antonio da Noli with Prince John. The two would have agreed all the steps Antonio da Noli had to take in case of a Castilian invasion of Santiago (Russell, 1971).

Although it is difficult, if not impossible, to confirm the existence and the terms of this supposed secret pact, it seems that Antonio da Noli maintained his role thanks to his skill and his high flexibility in adapting himself to the cir- 
cumstances of history and life. Nonetheless, in an episode of uncommon xenophobia by the Portuguese Cortes in 1481, a narrative by Lanciani highlights that a meaningful segment of Portuguese society considered Antonio da Noli as a foreign betrayer and mercenary. Through a popular petition, the Cortes required that "foreign people no longer had authorization to settle in Portugal or in the conquered lands". An explicit reference is made to "Florentines and Genoese" who, in their opinion, "never benefited these kingdoms." No doubt, according to Lanciani's count that Antonio da Noli had betrayed, concluding that this attitude "was beginning to produce its poisonous fruits" (Lanciani, 2006: p. 53).

Despite this interpretation that counters the positive image of Antonio da Noli, the relationship between this Ligurian navigator and the Portuguese crown did not break. As a matter of fact, in 1497, the administration of Santiago was passed to Antonio's daughter, Branca de Aguiar, with the only condition that she got married to someone welcome to the crown. She followed suit, marrying D. Jorge Correa, a noble man very near the Portuguese crown.

The legacy that Antonio da Noli left to the Fascist Italy did not represent a vantage for the valorization of this figure after the fall of Mussolini and the affirmation of a democratic and republican regime, in 1946. For, Antonio da Noli was forgotten, and almost disappeared from the Italian cultural context for a long time. A short reflection on his discoveries was conducted by Tullia Gasparrini Leporace in her introduction to the volume of Alvise da Ca' da Mosto's memories, thus with a focus on this Venetian navigator, and not on Antonio da Noli (Gasparrini Leporace, 1966).

The figure of Antonio da Noli returned to current events thanks to the work of Marcello Ferrada de Noli, a direct descendant of the Ligurian navigator who, after a brilliant academic carrier in epidemiology in Chile and Sweden and a political engagement as a prominent leftist exponent against the regime of Pinochet, decided to rescue the memory of Antonio da Noli, founding the aforementioned Antonio de Noli Academic Society. This Society tried to promote scientific studies on the figure of Antonio da Noli, obtaining important historical results (Noli, 2013b), "defascistizing" this figure and giving him a new international dimension, going beyond questions of nationalism and colonialism which had featured the disputes around this Ligurian navigator.

\subsection{The Debate on Antonio da Noli in Portugal}

The first Portuguese source that spoke of the discovery of Cape Verde is the navigator Diogo Gomes. According to his report, Gomes probably navigated together with Antonio da Noli to discover new lands. Diogo Gomes, according to his version, would be the first to sight the islands of Cape Verde: "I arrived firstly to one of these islands. I could see white sand, and it seemed to me a good port, where I anchored, and the same did Antonio. I told him that I wanted to be the first to touch that land, and so I did. There, we did not see any sign of human beings, and we called that island with the name of Santiago, and until today this is its name". The two navigators made the discovery at the same time, neverthe- 
less Gomes complained about his partner's treachery. For, Antonio da Noli decided to precede him at the court of Prince Henry, saying Henry that he discovered firstly these new lands. For this reason Henry was inclined to name him as a donate captain of Santiago Island: according to Gomes, Noli “arrived to Portugal first, before me. And he asked the king for the chieftainship of Santiago Island, which I had discovered, and the king gave it to him and he held it until his death" (Gomes, 1939). As explained above, Antonio da Noli did not write anything to confirm or deny this vexata quaestio, so a serious doubt remains on this important event.

In practice, Gomes claimed to have been defrauded of his discovery by Antonio da Noli, a fact that led to, as its immediate consequence, his exclusion from the administration of Cape Verde.

This first dispute between Antonio da Noli and Diogo Gomes nourished an articulated debate in Portuguese literature. As for the Italian perspective, and for Portugal's too, the period when the debate resumes around the discovery of Cape Verde is focused on the $19^{\text {th }}$ century. Nevertheless, in this phase the debate is free, and different trends appeared, with authors who defended the point of view of Diogo Gomes, and others who tended to identify Antonio da Noli as the actual discoverer of Cape Verde, and a third group that presented elements to show the presence of African and Arab populations in the archipelago before the arrival of the two navigators at the service of Portuguese crown. As reported above, it was with the systematization carried out by Salazar that this debate lost its variety of positions, being oriented, especially in occasion of the celebrations of the $500^{\text {th }}$ year of the discovery of Cape Verde, towards a clear path of nationalism and civilizing colonialism.

The background of this intense debate has been expressed by Barros in a recent study (Barros, 2017). As he correctly pointed out, a series of doubts about dates and circumstances of the discovery of Cape Verde provided an incomplete and precarious knowledge that made it easier to form scholarly speculations and theories. What is certain is that the perspective of the Portuguese debate is in part different from the Italian approach, at least in its first stage. In the Portuguese case, the focus is on the myth of the foundation of the colony and the Cape Verde society, interlaced with the Lusitanian pride related to the discovery of this archipelago, thanks to the Atlantic politics of Prince Henry (Barros, 2017).

A first, "ecumenical" trend was expressed by the Viscount of Santarém. Without focusing on who, among the famous navigators, first saw or occupied the Cape Verde islands, this author exalted the role of Portugal to explore those lands (de Santarém, 1842).

Another interpretation was given by Chelmicki, embedded in the idea of a previous arrival of people, probably coming from Africa, in Cape Verde before the arrival of the Portuguese navigators, although recognizing the latter's merit in the colonization of this archipelago (Chelmicki, 1841). The author theorized that Cape Verde was known since the ancient age expressly mentioned by writers as Strabo, Pliny and Ptolemy. Nevertheless, according to Barros (2017), the 
position expressed by Chelmicki was just a "legend", without any kind of documentation.

Yet during the $19^{\text {th }}$ century other authors, such as Lopes de Lima, in 1844, or Richard Mayor, in 1868, identified respectively Antonio da Noli and Diogo Gomes as the discoverers of Cape Verde (Barros, 2017).

At the beginning of the 1930s, the interpretation on the discovery of Cape Verde suffered a considerable modification. Coherently with the beginning of a general nationalization of the glorious Atlantic discoveries, Cortesão opened this new tendency recognizing just Diogo Gomes as the one who discovered Cape Verde (Cortesão, 1931). Nevertheless, the program of nationalization had not yet reached its maximum expression, leaving some space for other theories. José de Oliveira Boléo represented a historical and ideological position that tended to give value to the idea that the Italian Da Mosto and Antonio da Noli were the two main discoverers of Cape Verde, considering as "confused" the book of memories written by Diogo Gomes (Boléo, 1939).

This process of progressive nationalization which was incipient in the 1930s, about 30 years later became the ideological mark of the Portuguese studies around the discovery of Cape Verde. In a historical period characterized by a great wave of liberation of many Asian and African countries, Portugal continued to maintain its African colonies, plunging into a colonial war in 1961 and trying to transform its colonial approach in a supposed tolerant politics, based on a multiracial empire (Castelo, 2014).

This new period of reconsideration of the Portuguese Atlantic explorations had its beginning with the visit of the President of the Republic, Cravero Lopes, to Cape Verde, in 1955. In this circumstance, Lopes exalted the figure of Diogo Gomes promising the building of a monument in his honor.

Nevertheless, the culminant point of this process occurred in 1960, during the celebration of the $500^{\text {th }}$ years of the discovery of Cape Verde.

Among the authors who best expressed the Lusitanian nationalism and pride of the last part of Salazar governance, was Father António Brásio, one of the most coherent and intransigent. Explicitly, in a series of conferences held in Cape Verde (Barros, 2017), he expressed his discomfort for granting to Italy and its navigators the historical honor for having discovered the Cape-Verdean Islands. Every allusion to an anti-Lusitanian discourse was abolished, and the epopee of the Atlantic discoveries made in the $15^{\text {th }}$ century became an opportunity to show the generosity and resourcefulness of Portugal in relation to its colonies.

\subsection{The Debate on Antonio da Noli in Cape Verde}

The debate on Antonio da Noli and, more in general on the discovery of Cape Verde, counted the recent history of Cape Verde, as once a colonial possession of Portugal, and, since 1975, as an independent State.

During the colonial age the few Cape Verdean writers who dealt with the discovery of their archipelago expressed a point of view aligned to the colonial perspectives of their Portuguese colleagues. Or, to say better, in many circums- 
tances they manifested a sense of Lusitanian belonging and pride more accentuated and uniform than the Portuguese scholars above mentioned. This attitude can be explained through the minor degree of freedom that the Portuguese that came from the colonies enjoyed in relation to their colleagues from the metropolis.

The Cape Verdean poet, José Lopes, expressed this tendency (Lopes, 1929). In 1929, he praised "ostensibly (in majestic plural) the Lusitanian expansionistic epopee (which he designs as 'our navigations'), the navigators (which he adjectives as 'our famous navigators' or pilots at the service of Portugal) and the consequences deriving from these discoveries" (Barros, 2017: p. 96). Lopes was one of the three intellectuals who founded the journal Claridade (1936-1960). Another important writer of the same group was Baltazar Lopes, who accentuated the continuity between the Cape Verdean Creole and the Portuguese idiom (Resende, 2014).

After its political independence in 1975, Cape Verde saw the presence of at least three interpretations of its own discovery: one was radically anchored in a post-colonial vision, aimed at removing all the colonial vestiges, starting with the statue of Diogo Gomes in Santiago Island. A second was directed to celebrate the discovery of Cape Verde and continuing to emphasize the role of Portugal and its navigators. And the third and last one expressed a critical position against the Lusitanian colonialism, but without manifesting the radical perspectives of destroying physically statues and monuments of that age.

The first position was defended by Gilson Lopes Varela, who promoted a public petition against all the Portuguese figures who participated to the slave trade, starting from the statue in honor to Diogo Gomes (Varela, 2020). Varela stood for the dejection of all colonial vestiges through a strong argument: the colonial experience, especially in Cape Verde, had, as its typical feature-slavery. The political initiative of Varela is rooted in a perspective that was introduced in Cape Verde during the 1980s. As a matter of fact, the subject of slavery in Cape Verde, as shown above, in the Italian as well as in the Portuguese debate had been marginalized or removed, although it is close in relation to the Atlantic discoveries of Antonio da Noli, Diogo Gomes, Alvise da Ca' da Mosto and all the other navigators. A first study which emphasized the dichotomy of the Cape Verdean society-structured in privileged white against black or mulatto slaves-was published only in the 1980s (Carreira, 1983); hence, various other scholars gathered their inspiration and inclination toward the same perspective. Iva Cabral, in her research on the colonial elite in Cape Verde, emphasized the relations between the first colonization and the building of a slavery society, starting with the letter in which the Prince Fernando conceded to Antonio da Noli the captainship of the Southern part of Santiago Island (12/07/1466) (Cabral, 2013).

The political initiative of Varela represents the culminating point of a process of radical identity recovery that condemns the colonial past as a whole. To strengthen his idea, Varela gives concrete examples of how Cape Verde suffered permanent influence of a colonial mentality, also after its independence: the dis- 
trict Kwane Nkrumah was renamed Cravero Lopes, in honor to the former President of Portugal during the age of Salazar (1951-1958); the banknotes with the effigy of Amilcar Cabral were substituted with other with the image of grasshopper, turtle and other animals; someone tried to change the Day of the National Heroes (20/01) with the Day of Camões and the Lusitanian Communities (10/06); the Independence Day (05/07) was substituted with the first Election Day (13/01). Finally the change of the national flag and hymn was a clear attempt "to cancel the history of the struggle for liberation of Guinea Bissau and Cape Verde" (Varela, 2020).

If Varela's story represents the most radical approach against the Portuguese colonialism which started with the epopee of Prince Henry and his navigators, another important tendency embedded in a post-colonial perspective is shown by a line of study which tries to recover an autonomous identity, without entering in confrontation with colonialism. These studies emphasize the miscegenation of Cape Verde and defend its cultural and artistic patrimony as a whole, regardless for the historical age in which they were built (Ramos, 2010).

Finally, a last trend that is defined as "yet to be influenced" by a colonial approach. It is the perspective which Varela considers as the worst for the construction of a modern Cape Verdean identity, and that in 2020 organized a conference on "New information on Antonio da Noli and Christopher Columbus in Cape Verde and in Madeira Island", held by Marcelino Balla. The objective of this conference was to safeguard the artistic and museological patrimony of the archipelago, celebrating the $560^{\text {th }}$ year of the discovery of Cape Verde (WM/CP, 2020), remembering what occurred under the Salazar regime in 1960.

\section{Conclusion}

This research represented a first attempt to cross different perspectives on the first colonization of Cape Verde by the three countries involved in its discovery, namely Italy, Portugal and Cape Verde starting with the Ligurian navigator, Antonio da Noli.

As a matter of fact, Antonio da Noli was interpreted according to the ideological and political interests of the three nations above mentioned, also thanks to the scarce biographic information on him. These dark points allowed many observers to foster hypotheses not anchored into solid historical bases, "mis"representing Antonio da Noli according to their diversified points of view. This process was particularly evident in Italy and Portugal during the respective fascist regimes of Mussolini and Salazar, emphasizing the principles of patriotism, colonialism and the civilization mission of the Atlantic discoveries under Prince Henry.

In Italy, a more scientific study on Antonio da Noli was only recently developed, thanks to the initiative of Marcello Ferrada de Noli. In Portugal, the study of Barros published in 2017 represented a very effective synthesis of the Lusitanian tendencies on this figure as well as on the colonization of Cape Verde as a 
whole. Nevertheless it is evident that also after the overcoming of the fascist and nationalist perspective, Italy and Portugal tend to avoid a central argument which cannot be ignored speaking of Antonio da Noli or Diogo Gomes: the slave trade that probably all both helped to increase.

Using post-colonial theories as their background, this slippery subject was only raised by some Cape Verdean observers after obtaining political independence of their country. Nonetheless, in Cape Verde as well, there is no shortage of positions to evoke, directly or indirectly, a neo-colonial approach. This circumstance confirms that a figure as Antonio da Noli has to be studied in his multiple dimensions and interpretations, far beyond the eighteenth-century disputes on who arrived first to touch the new lands of Cape Verde.

\section{Conflicts of Interest}

The author declares no conflicts of interest regarding the publication of this paper.

\section{References}

Andrade, E. S. (1992). Le Cap-Vert dans l'expansion européenn. Praia.

Barros, V. (2017). A escrita da história da "descoberta" de Cabo Verde. Fabulário cronográfico, história oficial ou fabricação de consentimento? Práticas da História, 5, 75-113. http://www.praticasdehistoria.pt/

Bettinelli, S. (1786). Risorgimento d'Italia. Venezia: Ramondini.

Boléo, J. O. (1939). O Descobrimento e os Descobridores das Ilhas de Cabo Verde. Separata do Petrus Nonius, II, Fasc. 3.

Bussotti, L. (2008). La modernità di Alvise da ca' da Mosto. In: L. Bussotti, \& S. Ngoenha (Eds.), La Guinea-Bissau contemoranea. Studi post-coloniali (pp. 27-38). Torino: L'Harmattan Italia.

Ca' da Mosto, A. da (1966). Il nuovo Ramusio. Le navigazioni atlantiche di Alvise da Mosto. Roma: Istituto Poligrafico dello Stato.

Cabral, I. M. (2013). A primeira elite colonial atlântica. PHD Thesis. Praia: University of Cape Verde.

Caraci, G. (1961). L'Italia e il Principe Enrico. Napoli: “Annali dell'Istituto Universitario Orientale", III.

Carletti, F. (1941). Giro del mondo del buon negriero (1594-1606). Milano: Bompiani.

Carreira, A. (1983). Cabe Verde-Formação e Extinção de uma Sociedade Escravocrata (1460-1878). Lisboa: Instituto Caboverdiano do Livro.

Castelo, C. (2014). “Novos Brasis” em África: desenvolvimento e colonialismo português tardio. Varia História, 30, 507-532.

https://www.scielo.br/scielo.php?script=sci_arttext\&pid=SO104-87752014000200009 https://doi.org/10.1590/S0104-87752014000200009

Chelmicki, J. C. C. (1841). Cronografia caboverdiana. Lisboa: Typografia de L.C. da Cunha.

Cortesão, A. Z. (1931). Subsídios para a História do Descobrimento da Guiné e de Cabo Verde. Boletim da Agência Geral das Colónias, A. VII, 76, 3-39.

de Santarém, V. (1842). Recherche sur la priorité de la découverte des Pays situés sur la 
Côte Ocidental d'Afrique, au-delá du Cap Bojador, et sur les progrès de la Science Géographique, aprés les navigations des Portuguais, au $X V^{e}$ Siècle. Paris: La Librarie Oriental de $\mathrm{V}^{\mathrm{e}}$ Dondey-Dupré: Librarie des Sociétés Asiatiques et Ethnologique. https://doi.org/10.2307/1797988

Descalzo, G. (1943). Antonio da Noli. Milano: Zucchi.

Enciclopedia Europea (1976) Vol. I, p. 514, Garzanti, Milano.

Ferreira Cascão, R. A. (1992). As correntes nacionalistas da segunda década do século XX. Revista da História das Ideias, 14, 325-345. https://doi.org/10.14195/2183-8925_14_14

Ferro, G. (1980). I navigatori portoghesi sulla via delle Indi. Milano: Mursia.

Gandoglia, B. (1885). La città di Noli. Savona: Tip. Bartoletta e Isotta.

Gasparrini Leporace, T. (Ed.) (1966). Il nuovo Ramusio V. Le Navigazioni Atlantiche del Veneziano Alvise da Mosto. Roma: Istituto Poligrafico dello Stato.

Gomes, D. (1939). De prima iuentione Gujnee. In: Fontoura da Costa, A. (Ed.). Cartas das ilhas de Cabo Verde de Valentim Fernandes 1506-1508 (pp. 187-207). Lisboa: Ática.

Hobsbawm, E., \& Ranger, T. (1983). The Invention of Tradition. Cambridge: Cambridge University Press.

Lanciani, G. (2006). Morfologie del viaggio. L'avventura marittima portoghese. Milano: LED.

Lopes, F. (1960). A figura e a obra do Infante D. Henrique. Lisboa: Portugalia Editora.

Lopes, J. (1929). Arquipélago de Cabo Verde. Boletim da Agência Geral das Colónias, Ano $V, 45,204-214$.

Meriggi, M., \& Schiera, P. (Eds.) (1993). Dalla città alla nazione. Borghesie ottocentesche in Italia e in Germania. Bologna: Il Mulino.

Noli, M. F. (2013a). The Genoese Nationality of Governor Antonio de Noli. Research Bullettin of the Antonio de Noli Academic Society, 5, 21-62.

Noli, M. F. (Ed.) (2013b). Antonio de Noli and the Beginning of the New World Discoveries. Sweden: Libertarian Books.

Peluffo, A. (Ed.) (2013). Da Noli a Capo Verde. Savona: Marco Sabatelli Editore.

Pescio, A. (1913). I grandi navigatori liguri. Roma: Sezione di Genova della Lega Navale Italiana.

Prevost D’Exiles, A. F. (1784). Istoria Generale de’Viaggi. Venezia: Formaloni.

Putnam, R. D., Leonardi, R., \& Nanetti, R. Y. (1993). La tradizione civica nelle regioni italiane. Milano: Mondadori.

Radulet, C. M. (1983). Documenti delle scoperte portoghesi. I. Le premesse. Bari: Adriatica Editrice.

Ramos, R. C. S. (2010). Património e memória: Estudo de caso, a ilha de Santiago, Cabo Verde. Master Thesis, Faculty of Arts. Lisboa: Universidade de Lisboa.

Resende, T. (2014). Colonialismo e Cabo Verde: Discussões sobre a colonização portuguesa na África (1950 e 1960). Temporalidades, 6, 184-199. https://periodicos.ufmg.br/index.php/temporalidades/article/download/5549/3479/

Russell, P. E. (1971). Fontes documentais castelhanas para a história da expansão portuguesa na Guiné nos ultimos anos de D. Afonso V. Do tempo e da história, IV (pp. 5-33). Lisboa: Instituto de Alta Cultura.

Salvadori, R. (1942). Antoniotto Usodimare. Milano: Oberdan Zucchi.

Spotorno, G. B. (1824-1826). Storia letteraria della Liguria, 4 voll. Genova: Ponthenier.

Tenenti, A. (1980). La formazione del mondo moderno. XIV/XVII secolo. Bologna: Il 
Mulino.

Ufficio del Capo di Stato Maggiore della Regia Marina (1931). Onomastica navale. Roma: Tipografia dell'Ufficio di Stato Maggiore Regia Marina.

Varela, A. T. (2020). A história da nossa história. Santiagomagazine, 19/07/2020.

https://santiagomagazine.cv/index.php/mais/n-colunista/4592-a-historia-da-nossa-hist oria

Verrecchia, A. (2002). Giordano Bruno: la falena dello spirito. Roma: Donzelli.

WM/CP (2020). Praia acolhe conferência "Novas Informações sobre Antonio de Noli e Cristovão Colombo em Cabo Verde e na Madeira”. In: Infopress.cv, 08/1/2020.

Zuarara, G. E. de (1915). Crónica da Tomaia de Ceuta por el Rei D. João I. Lisboa: Accademia das Ciências.

Zuarara, G. E. de (w.d.). Crónica da Guiné. Lisboa: Livraria Civilização.

Zurla, P. (1815). Dei viaggi e delle scoperte africane. Venezia: Alvisopoli. 